\title{
EDITORIAL
}

Pablo Fuentes Hernández Gonzalo Cerda Brintrup

\section{NUEVOS PARADIGMAS ¿NUEVA ARQUITECTURA?}

Paradigma es el término que identifica a una teoría o el conjunto de ellas cuyo centro o eje, es aceptado sin cuestión, y en consecuencia ofrece la base y el modelo para zanjar problemas y progresar en el conocimiento.

Hasta ahora, el origen de los paradigmas, esa génesis aparentemente perfecta, redonda y simple, parecía inevitablemente asida a unas determinantes históricamente justificadas que siempre pertenecían a tiempos pasados. De ese modo, la distancia temporal para su examen no ofrecía cuestionamientos sobre su nacimiento y sus causas; dicho de otra manera, el paradigma ya existía, nosotros llegamos después a examinarlo.

2020 se mostró como un año cero. Es cuando los corredores están en la línea de salida expectantes ante el disparo que haga oportuna la partida. La pandemia del covid 19 en el ámbito mundial, y el estallido social de 2019 en Chile, son hechos que dibujan un espacio-tiempo que se asimilan a un devenir eterno. En nuestro caso, incluso, todo indica que la evolución de uno depende del progreso del otro. La espera quieta, se hace insoportable; la esperanza segura, inalcanzable. Ambos hechos están a la espera de comenzar una carrera incierta que promete cambios, giros y vuelcos de los que sólo esperamos beneficios.

En el horizonte, una mirada reposada indica que, como contraparte de una cultura oficial, irrumpe una cultura híbrida y mestiza. Las palabras de Venturi, dichas hacen ya casi 60 años, cobran renovada vigencia.

\begin{abstract}
Defiendo la riqueza de significados en vez de la claridad de significados; la función implícita a la vez que la explicita. Prefiero 'esto y lo otro' a 'o eso o lo otro', el blanco y el negro, y algunas veces el gris, al negro o al blanco. Una arquitectura válida evoca muchos niveles de significados y se centra en muchos puntos: su espacio y sus elementos se leen y funcionan de varias maneras a la vez. (Venturi, 1962). ${ }^{1}$
\end{abstract}

En lo más simple -que no lo es-, el espacio doméstico, acaso hoy el lugar de uso más inmediato, ha aumentado su polifuncionalidad y, consecuentemente, su percepción. La realidad advertida parece una vista fragmentada que se atisba más allá de la ventana, que, por lo mismo, muestra menos que lo que oculta. El encierro, imprescindible para la sobrevivencia, parece demandar nuevos significados del verbo habitar y una revisión del sustantivo habitación. Hasta hace poco, el espacio público había demandado toda la atención para corregir unos modos segregados, empobrecidos, periféricos. Hoy el espacio interior exige esmero, cuidado y diligencia. Si el primero expone, el segundo protege.

Una mirada disciplinar implica que nuevos cruces, mixturas, combinaciones, obliguen a nuevas lecturas. Es así como, por una parte, los espacios aislados ahora están atentos a mejores soluciones; y por otra, los espacios naturales abiertos, parques y campos, son ensoñados como un ambiente sano e inmune.

Arquitecturas del Sur se abre a indagar, y acaso descubrir esos nuevos mundos, que van acompañados por fenómenos socioculturales como la incorporación equivalente de la mujer, hasta el respeto por la diversidad; desde los nuevos modos de trabajo -cada vez más colectivos y participativos-, hasta el respeto por el patrimonio y la biodiversidad. La sustentabilidad, la equidad social, el progreso tecnológico, le democratización de los géneros, son fenómenos que emergen a la espera de ser acogidos por nuevas formas. Proponemos detectar aquellos nuevos paradigmas y examinar su traducción a nuevos lenguajes; escudriñar el futuro para atisbar nuevos derroteros. En este marco, la arquitectura está frente a nuevas preguntas, relatos y reinterpretaciones, y por ello cabe preguntar: ¿tendrá nuevas respuestas?, ¿cuáles son aquellos nuevos paradigmas y cuáles aquellas obras que los interpretan $y$ traducen? 


\section{NEW PARADIGMS, NEW ARCHITECTURE?}

Paradigm is the term that identifies a theory or set of theories whose core or axis are unquestionably accepted, and consequently offers the basis and model for solving problems and progressing in knowledge.

Until now, the origin of paradigms, that apparently perfect, rounded, and simple genesis, seemed inevitably tied to historically justified determining factors that always belonged to past times. Thus, the temporal distance for their examination did not offer questions about their emergence and causes; in other words, the paradigm already existed, we arrived later to examine it.

2020 showed itself to be a year zero. It is when the runners are at the starting line, waiting for the gun to set off. The covid-19 pandemic on a global scale, and the 2019 social uprising in Chile, are events that draw a space-time that can be assimilated to an eternal becoming. Even in our case, everything indicates that the evolution of one depends on the progress of the other. Calmly waiting becomes unbearable, certain hope, unattainable. Both facts are waiting to begin an uncertain race that promises changes, twists and turns from which we only hope for benefits.

On the horizon, a calm look indicates that, as a counterpart to an official culture, a hybrid and mestizo culture is bursting forth. Venturi's words, spoken almost 60 years ago, have renewed relevance.

\footnotetext{
I advocate richness of meaning, rather than clarity of meaning; implicit rather than explicit role. I prefer 'this and that' to 'that or the other', black and white, and sometimes grey, to black or white. A valid architecture evokes many levels of meaning and focuses on many points: their space and elements are read and work in several ways at the same time. (Venturi, 1962). ${ }^{1}$
}

At the simplest level, the domestic case, although there is nothing simple about it, perhaps today the place of most immediate use, has increased its polyfunctionality and, therefore, its perception. The reality seems like a fragmented view that is visualized beyond the window, which, by the same token, shows less than it hides. Lockdown, essential for survival, seems to demand new meanings of the verb "to inhabit" and a revision of the noun "room". Until recently, public space had demanded all the attention to correct some segregated, impoverished, peripheral modes. Today, indoor space demands care, attention and diligence. If the former exposes, the latter protects.

A disciplinary view implies that new crossings, mixtures, combinations, force new readings. This is how, on one hand, isolated spaces are now attentive to better solutions; and on the other, natural open spaces, parks and fields, are yearned for as a healthy and immune environment.

Arquitecturas del Sur is open to investigate and perhaps discover these new worlds, which are accompanied by socio-cultural phenomena such as the equivalent incorporation of women, to the respect for diversity; from new ways of working -increasingly collective and participative- to the respect for heritage and biodiversity. Sustainability, social equity, technologi$\mathrm{cal}$ progress, gender democratization, are phenomena that are emerging and waiting to be embraced in new ways. We propose detecting these new paradigms and examining their translation into new languages; to scrutinise the future in order to glimpse new directions. In this framework, architecture faces new questions, narratives and reinterpretations, and therefore it is worth asking: will it have new answers, what are those new paradigms, and what are the works that interpret and translate them?

\section{NOVOS PARADIGMAS, NOVA ARQUITETURA?}

Paradigma é o termo que identifica uma teoria ou conjunto de teorias cujo centro ou eixo é aceito sem questionar e que, consequentemente, oferece a base e o modelo para resolver problemas e progredir no conhecimento.

Até agora, a origem dos paradigmas, uma gênese aparentemente perfeita, redonda e simples, parecia inevitavelmente ligada a determinantes historicamente justificados que sempre pertenceram a tempos passados. Assim, a distância temporal para o seu exame não implicava questionamentos sobre seu nascimento e suas causas; em outras palavras, o paradigma já existia e chegamos, posteriormente, para examiná-lo.

2020 revelou-se como um ano zero. É quando os corredores estão na linha de partida à espera do tiro que fará com que a partida seja oportuna. A pandemia de covid-19 no mundo e a explosão social de 2019 no Chile são fatos que desenham um espaço-tempo que se assimila a um devir eterno. Em nosso caso, aliás, tudo indica que a evolução de um depende do progresso do outro. A espera tranquila torna-se insuportável; a esperança e a certeza, inalcançáveis. Ambos os fatos aguardam o início de uma corrida incerta que promete mudanças e reviravoltas das quais apenas esperamos benefícios.

No horizonte, um olhar calmo indica que, como contrapartida a uma cultura oficial, irrompe uma cultura híbrida e miscigenada. As palavras de Venturi, proferidas há quase 60 anos, têm sua relevância renovada.

Defendo a riqueza de significados em vez da clareza de significados; a função implícita em paralelo à explícita. Prefiro "isto e aquilo" a "ou isto ou aquilo", o preto e o branco, e por vezes o cinza, ao preto ou branco. Uma arquitetura válida evoca muitos níveis de significado e concentra-se em muitos pontos: seu espaço e seus elementos são lidos e funcionam de várias maneiras ao mesmo tempo. (Venturi, 1962).

Na sua forma mais simples -que não o é-, o espaço doméstico, talvez hoje o local de utilização mais imediata, aumentou sua polifuncionalidade e, consequentemente, sua percepção. A realidade vista parece uma visão fragmentada que se entrevê para além da janela e que, pela mesma razão, mostra menos do que oculta. O confinamento, imprescindível para a sobrevivência, parece exigir novos significados do verbo "habitar" e uma revisão do substantivo "habitação". Até há pouco, o espaço público exigia toda a atenção para corrigir os modos segregados, empobrecidos e periféricos. Atualmente, o espaço interior exige esmero, cuidado e diligência. Se o primeiro expõe, o segundo protege.

Um olhar disciplinar implica que novos cruzamentos, misturas e combinações forçam novas leituras. É assim que, por um lado, os espaços isolados estão agora atentos a melhores soluções; e, por outro, os espaços abertos naturais, parques e campos, são sonhados como um ambiente saudável e imune.

Arquitecturas del Sur abre-se para investigar e talvez descobrir esses novos mundos, que são acompanhados por fenômenos socioculturais que vão da incorporação equivalente das mulheres até o respeito pela diversidade; das novas formas de trabalho -cada vez mais coletivas e participativas- até o respeito pelo patrimônio e pela biodiversidade. Sustentabilidade, equidade social, progresso tecnológico, democratização dos gêneros, são fenômenos que emergem à espera de serem abraçados por novas formas. Propomos detectar estes novos paradigmas e examinar sua tradução a novas linguagens; ponderar o futuro de modo a vislumbrar novas rotas. Neste sentido, a arquitetura enfrenta novas questões, narrativas e reinterpretações, pelo que vale a pena perguntar: terá novas respostas, quais são esses novos paradigmas e quais são as obras que os interpretam e traduzem? 